\title{
Maize inbreds from different heterotic groups as favorable sources for increased potential bioavailability of magnesium, iron, manganese and zinc
}

\author{
Vesna Dragicevic ${ }^{1 *}$, Snezana Mladenovic-Drinic ${ }^{1}$, Milovan Stojiljkovic ${ }^{2}$, \\ Milomir Filipovic ${ }^{1}$, Bogdan Nikolic ${ }^{3}$, Vojka Babic ${ }^{1}$, and Natalija Kravic ${ }^{1}$
}

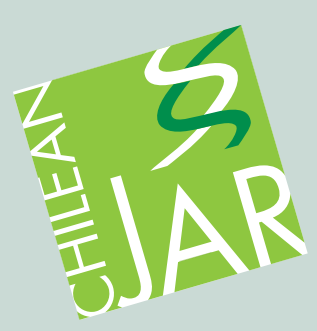

\section{ABSTRACT}

Malnutrition, as a global problem, is mainly caused by low level of mineral elements in staple food (deficient soil). Biofortification is based on selection of genotypes with enhanced concentration of mineral elements in grain, as well as decreased concentration of substances which interfere bioavailability of mineral elements in gut (like phytic acid), and increased content of substances that increase availability (such as $\beta$-carotene). The experiment with 51 maize (Zea mays L.) inbred lines with different heterotic background was set up in order to evaluate chemical composition of grain and to determine the relations between phytic acid (PA), $\beta$-carotene, and mineral elements: $\mathrm{Mg}, \mathrm{Fe}, \mathrm{Mn}$, and $\mathrm{Zn}$. The highest average phytate, $\beta$-carotene, $\mathrm{Fe}$, and $\mathrm{Mn}$ content was found in grain of inbreds from Lancaster heterotic group. The highest content of $\mathrm{Mg}$ was in grain of Independent source and $\mathrm{Zn}$ in grain of BSSS group. Increased level of Fe and $\mathrm{Mn}$ in Lancaster lines could be partially affected by higher PA content in grain, while increased $\beta$-carotene content could improve $\mathrm{Mn}$ and $\mathrm{Zn}$ availability from grain of BSSS genotypes and $\mathrm{Mg}$ availability from Lancaster inbreds. It is important to underline that PA reduction is followed by $\mathrm{Zn}$ content increase in grain of Lancaster heterotic group, as well as that variations in $\mathrm{Mg}, \mathrm{Fe}$, and $\mathrm{Mn}$ contents are independent on PA status in inbreds from Independent source, indicating that the genotypes with higher $\mathrm{Mg}, \mathrm{Fe}$ and $\mathrm{Mn}$ status from this group could serve as favorable source for improved $\mathrm{Mg}, \mathrm{Fe}$, and $\mathrm{Mn}$ absorption.

Key words: Bioavailability, $\beta$-carotene, heterotic group, inbred line, mineral elements, phytic acid.

${ }^{1}$ Maize Research Institute Zemun Polje, Slobodana Bajića 1, 11185 Zemun Polje, Serbia. "Corresponding author (vdragicevic@mrizp.rs). ${ }^{2}$ Vinca Institute of Nuclear Sciences, P. fah 522, 11001 Belgrade, Serbia.

${ }^{3}$ Institute for Plant Protection and Environment, Teodora Drajzera 9, 11000 Belgrade, Serbia.

Received: 6 August 2015.

Accepted: 1 December 2015.

doi:10.4067/S0718-58392016000200011

\section{INTRODUCTION}

For optimal functioning, human body requires more than 22 mineral elements. Their intake could be restricted due to nutritional habits (i.e., vegetarian diets, avoidance of certain food type, etc.) or low level of mineral elements existing in staple food. Each of these factors could lead to malnutrition, having as a consequence numerous health problems, such as anemia, abnormal blood losses, chronic inflammatory stress, obesity, atherosclerosis, hypertension, osteoporosis, diabetes mellitus, and cancer (Hunt, 2003; White and Broadley, 2005; Nielsen, 2010).

Biofortification, aimed to enhance mineral elements concentrations and/or bioavailability in edible plant tissues, either agronomically or genetically using both conventional breeding and modern biotechnology, is considered to be the most promising and costeffective approach to alleviate mineral malnutrition (Cakmak, 2008). The accumulation of minerals in seeds is a complex phenomenon, which is most likely controlled by a number of genes (Ghandilyan et al., 2009). The movement of mineral elements from soils to seeds involves their mobilization from soils, uptake by roots, translocation to the shoot, redistribution within the plant and deposition in seeds (Welch, 2003; White and Broadley, 2009).

Increase of mineral elements concentration in grain through breeding as a method for biofortification (White and Broadley, 2005), includes also a decrease of substances that interfere the absorption or utilization of mineral elements in gut. Namely, antinutrients (inhibitors), like phytate, polyphenolics etc., limit the absorption of mineral elements, whereas promoters (enhancing substances), such as ascorbate, $\beta$-carotene, S-containing amino acids, etc., promote mineral nutrients bioavailability or decrease the activity of inhibitors (Welch and Graham, 2004; Germano and Canniatti-Brazaca, 2011). Besides the processing for phytic acid (PA) reduction in foods (Bohn et al., 2008; Ramirez-Cardenasi et al., 2008), one of the important goals of biofortification is selection of genotypes with low content of phytic acid (lpa). Naturally occurred mutations, like in maize (Zea mays L.), could have as a result normal level of total $\mathrm{P}$ but with significantly reduced PA level in grain, which in turn increases the level of inorganic $\mathrm{P}\left(\mathrm{P}_{\mathrm{i}}\right)$ (Lönnerdal, 2003). For biofortification purposes, it is also important to identify genetic resources with high levels of the targeted mineral elements (especially when growing on soils with low level and/or reduced availability of targeted mineral elements), to consider the heritability of the targeted traits and to investigate Genotype $\times$ Environment interactions (Ortiz-Monasterio et al., 2007). 
Although dietary phytate has received much attention as an antinutrient, more recent scientific studies support different beneficial properties of phytate in humans on several civilization diseases: antioxidative effect (particularly in regards to $\mathrm{Fe}$ ), preventing pathological calcification, e.g. kidney stones and calcification in the heart vessels, cholesterol lowering effects and anticancer activity (Konietzny et al., 2006). Reported positive roles of phytic acid, along with the fact that is the major storage compound of $\mathrm{P}$ in cereals and legumes grains (Bohn et al., 2008; Branković et al., 2015), lead to necessity for achievement of homeostasis, i.e. for maintaining of optimal level between phytic acid and mineral elements.

Maize is a widely consumed multipurpose crop. Since nutrient quantities and bioavailability are, among other factors, influenced by genetics, information on genetic diversity and heterotic groups is very useful in evaluation for planning inbred lines crosses for hybrid cultivar development. All those findings prompt us to evaluate the variability of different maize genotypes for increased bioavailability of targeted mineral elements important to human nutrition. Considering the low level of some mineral nutrients caused by long-term inputs of NPK and N fertilizers, the experiment was conducted on 51 maize inbred lines with different heterotic background, in order to (i) evaluate chemical composition of grain and (ii) to determine the relations between phytic acid, and $\beta$-carotene, as factors affecting the absorption of mineral elements, i.e. $\mathrm{Mg}, \mathrm{Fe}, \mathrm{Mn}$, and $\mathrm{Zn}$.

\section{MATERIALS AND METHODS}

The experiment was carried out in 2010 and 2011 in Zemun

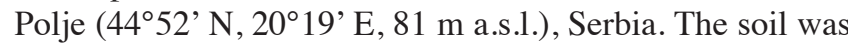
slightly calcareous chernozem (Zivkovic et al., 1972), with: $53.0 \%$ sand, $30.0 \%$ silt, $17.0 \%$ clay, $3.3 \%$ organic matter, $7.17 \mathrm{pH} \mathrm{KCl}$, and $7.40 \mathrm{pH} \mathrm{H}_{2} \mathrm{O}$. The texture was silty clay loam, containing: $37.45 \mathrm{mg} \mathrm{kg}^{-1}$ of available $\mathrm{N}, 10.70 \mathrm{mg}$ $\mathrm{kg}^{-1} \mathrm{P}, 107.40 \mathrm{mg} \mathrm{kg}^{-1} \mathrm{~K}, 3270.00 \mathrm{mg} \mathrm{kg}^{-1} \mathrm{Ca}, 327.95 \mathrm{mg}$ $\mathrm{kg}^{-1} \mathrm{Mg}, 0.65 \mathrm{mg} \mathrm{kg}^{-1} \mathrm{Fe}, 0.20 \mathrm{mg} \mathrm{kg}^{-1} \mathrm{Mn}$, and $<0.02 \mathrm{mg}$ $\mathrm{kg}^{-1} \mathrm{Zn}$ and $4,7 \% \mathrm{CaCO}_{3}$ in 0-30 cm layer. Available $\mathrm{N}$ was determined by the method of Scharpf and Wehrmann (1975), $P$ was determined by method of Watanabe and Olsen (1965), and $\mathrm{K}, \mathrm{Ca}, \mathrm{Mg}, \mathrm{Fe}, \mathrm{Mn}$ and $\mathrm{Zn}$ by inductively coupled plasma-optical emission spectrometry (Spectroflame, 27.12 $\mathrm{MHz}$ and $2.5 \mathrm{~kW}$, model P, Spectro Analytical Instruments, Kleve, Germany) after extraction by procedure of Mechlich (1984). $\mathrm{CaCO}_{3}$ was determined by the method of Horváth et al. (2005). Fertilization was followed by $400 \mathrm{~kg} \mathrm{ha}^{-1}$ of NPK (15:15:15) in the autumn and $300 \mathrm{~kg} \mathrm{ha}^{-1}$ of urea in the spring, before sowing.

Fifty-one maize inbred lines from Maize Research Institute "Zemun Polje" were the objective of the present study. A randomized complete block design with four replicates was used in the experiment. Examined inbreds have different heterotic background: 20 inbreds (from L1 to L20) belong to $B S S S$ heterotic group, 17 inbreds (from L21 to L37) belong to Lancaster heterotic group, while 13 inbreds (from L38 to L51) represent independent source, respectively. After harvesting and drying to $14 \%$ water content, chemical composition of grain was determined. Phytic $\left(\mathrm{P}_{\text {phy }}\right)$ and inorganic $\mathrm{P}\left(\mathrm{P}_{\mathrm{i}}\right)$ were determined spectrophotometrically by the method of Dragičević et al. (2011). $\beta$-Carotene was determined according to American Association of Cereal Chemists Method (AACC, 1995). Mineral elements (Mg, $\mathrm{Fe}, \mathrm{Mn}$, and $\mathrm{Zn}$ ) were determined after wet digestion with $\mathrm{HNO}_{3}+\mathrm{HClO}_{4}$, by inductively coupled plasma-optical emission spectrometry.

\section{Statistical analysis}

Analyses of chemical composition of grain were performed in four measurements $(n=4)$ and the experimental data were

Table 1. Analysis of variance for the effect of genotype, year and Genotype $\times$ Year interaction on phytic $\left(P_{\text {phy }}\right)$ and inorganic $P\left(P_{i}\right)$, $\beta$-carotene, $\mathrm{Mg}, \mathrm{Fe}, \mathrm{Mn}$, and $\mathrm{Zn}$ contents in grain of 51 commercial maize inbred lines.

\begin{tabular}{|c|c|c|c|c|c|c|c|c|}
\hline \multirow[b]{2}{*}{ Source of variation } & \multirow[b]{2}{*}{ df } & \multirow{2}{*}{$\begin{array}{l}P_{\text {phy }} \\
\text { MS }\end{array}$} & \multirow{2}{*}{$\frac{\mathrm{P}_{\mathrm{i}}}{\mathrm{MS}}$} & \multirow{2}{*}{$\frac{\beta \text {-carotene }}{\mathrm{MS}}$} & \multirow{2}{*}{$\frac{\mathrm{Mg}}{\mathrm{MS}}$} & \multirow{2}{*}{$\frac{\mathrm{Fe}}{\mathrm{MS}}$} & \multirow{2}{*}{$\begin{array}{l}\text { Mn } \\
\text { MS }\end{array}$} & \multirow{2}{*}{$\frac{\mathrm{Zn}}{\mathrm{MS}}$} \\
\hline & & & & & & & & \\
\hline & & 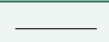 & 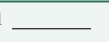 & & 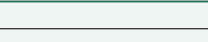 & $-\mu g g^{-1}$ & & 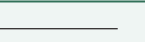 \\
\hline Replicate & 3 & 0.060 & 0.000 & 0.582 & 1139.993 & 3.599 & 0.005 & 8.287 \\
\hline Inbred line (IL) & 50 & $0.623 * *$ & $0.066^{* *} *$ & $139.989 * *$ & $35401.659 * *$ & $212.892 * *$ & $14.573 * *$ & $256.311 * *$ \\
\hline Year $(Y)$ & 1 & $5.678 * *$ & $0.117 * *$ & $1860.836 * *$ & $17708854.170 * *$ & $9008.256 * *$ & $307.117 * *$ & $1933.544 * *$ \\
\hline $\mathrm{IL} \times \mathrm{Y}$ & 50 & $0.644 * *$ & $0.028 * *$ & $26.990 * *$ & $15388.952 * *$ & $178.642 * *$ & $5.607 * *$ & $158.99 * *$ \\
\hline Error & 303 & 0.021 & 0.0001 & 0.479 & 38.897 & 0.812 & 0.066 & 4.730 \\
\hline $\mathrm{CV}, \%$ & & 4.03 & 4.07 & 5.68 & 1.06 & 7.20 & 5.48 & 9.55 \\
\hline LSD (IL) 0.05 & & 0.146 & 0.010 & 0.695 & 6.263 & 0.905 & 0.258 & 2.184 \\
\hline Average & $B S S S$ & 3.57 & 0.45 & 12.86 & 584.68 & 12.61 & 4.52 & 23.87 \\
\hline Min & & 3.22 & 0.33 & 7.43 & 455.16 & 3.89 & 2.83 & 15.60 \\
\hline Max & & 4.20 & 0.64 & 20.26 & 687.97 & 20.30 & 7.24 & 40.70 \\
\hline Average & Lanc. & 3.67 & 0.52 & 13.05 & 581.90 & 12.95 & 5.06 & 20.93 \\
\hline Min & & 3.04 & 0.35 & 3.56 & 520.00 & 3.81 & 2.68 & 13.57 \\
\hline $\operatorname{Max}$ & & 4.35 & 0.62 & 21.40 & 676.56 & 22.03 & 8.05 & 29.47 \\
\hline Average & Indep.source & 3.56 & 0.51 & 10.16 & 594.25 & 11.85 & 4.47 & 23.43 \\
\hline Min & & 3.01 & 0.33 & 2.64 & 458.28 & 5.47 & 2.59 & 17.20 \\
\hline $\operatorname{Max}$ & & 3.84 & 0.68 & 17.55 & 731.72 & 28.09 & 6.75 & 34.93 \\
\hline
\end{tabular}

*Significant at $5 \%$ probability level; df: degrees of freedom; MS: mean squares. 
subjected to two-way ANOVA. The coefficient of variation (CV) was determined for each trait, while significant differences between genotypes means were determined by the Fisher's least significant difference (LSD) test at the 0.05 probability level. Differences with $\mathrm{P} \leq 0.05$ were considered as significant. Ratios $\mathrm{P}_{\text {phy }} / \mathrm{P}_{\mathrm{i}}$, phytic acid (PA) $/ \beta$-carotene, $\mathrm{PA} / \mathrm{Mg}, \mathrm{PA} / \mathrm{Fe}, \mathrm{PA} / \mathrm{Mn}$, and $\mathrm{PA} / \mathrm{Zn}$ were presented as mean \pm standard deviation (SD). For inbreds within each heterotic group, regression analysis and principal component analysis (PCA) were used for evaluation of interdependence between $\mathrm{P}_{\text {phy }}$ and mineral elements, as well as between $\beta$-carotene and mineral elements. Statistical analysis was performed by SPSS 15.0 (IBM Corporation, Armonk, New York, USA) for Windows Evaluation version.

\section{RESULTS AND DISCUSSION}

In this study has been shown that effect of genotype (e.g., inbred line), year, and their interaction had significant impact on variation in $\mathrm{P}_{\text {phy }}, \mathrm{P}_{\mathrm{i}}, \beta$-carotene, $\mathrm{Mg}, \mathrm{Fe}, \mathrm{Mn}$, and $\mathrm{Zn}$ content in grain, as presented in Table 1 . The highest variation between genotypes was observed for mineral elements contents, particularly for Fe and $\mathrm{Zn}$, which could be reflected on different ability of the examined maize inbred lines to absorb and accumulate those elements (Kovačević et al., 2004). That is particularly important for genotypes growing on soils with low level and/or reduced availability of some mineral elements (Lynch and St.Clair, 2004). The highest average $\mathrm{P}_{\text {phy }}, \mathrm{P}_{\mathrm{i}}, \beta$-carotene, $\mathrm{Fe}$ and $\mathrm{Mn}$ content was found in grain of inbreds from Lancaster heterotic group. The results obtained are opposed to the results of MladenovićDrinić et al. (2013), who asserted that genotypes from Lancaster germplasm were low in $\mathrm{P}$ and Fe. However, the highest content of $\mathrm{Mg}$ was found in grain of inbreds belong to Independent source and $\mathrm{Zn}$ in grain of inbreds belong to BSSS group. This could mean that genotypes from Lancaster group are efficient to acquire Fe and Mn and from BSSS to acquire $\mathrm{Zn}$ from substrate poor in their content (Kovačević et al., 2004).

Based on the molar ratios between PA and mineral elements, such as $\mathrm{PA} / \mathrm{Zn}$ and $\mathrm{PA} / \mathrm{Fe}$, it is possible to determine genotypes (or foods) with potentially high $\mathrm{Fe}$ and $\mathrm{Zn}$ bioavailability (Ma et al., 2007; Queiroz et al., 2011). According to relatively high content of examined mineral elements, lower mean values of PA/Fe and PA/ Mn (98.59 and 221.94, respectively) were observed in grain of Lancaster group (Table 2). For inbreds belong to Independent source, lower $\mathrm{P}_{\text {phy }} / \mathrm{P}_{\mathrm{i}}$ and $\mathrm{PA} / \mathrm{Mg}$ ratios were found (7.21 and 0.80, respectively). Among BSSS lines, the lowest PA/ $\beta$-carotene was present in grain of L10 (491.3), which along with relative low values of $\mathrm{PA} / \mathrm{Mg}$ and $\mathrm{PA} / \mathrm{Mn}$ ( 0.73 and 180.7 , respectively) could indicate their improved bioavailability (Queiroz et al., 2011). The lowest PA/Mn ratio among all examined lines was present in L27 (146.1), the inbred from Lancaster heterotic group with relatively low PA/ $\beta$-carotene ratio (663.05), which could be reflected on better Mn availability. Among inbreds from Independent
Table 2. Molar ratios between phytic $\mathbf{P}\left(\mathbf{P}_{\text {phy }}\right) /$ inorganic $\mathbf{P}\left(\mathbf{P}_{\mathrm{i}}\right)$, phytic acid (PA)/ $\beta$-carotene, PA/Mg, PA/Fe, and PA/Zn.

\begin{tabular}{|c|c|c|c|c|c|c|}
\hline & $\mathrm{P}_{\text {phy }} / \mathrm{P}_{\mathrm{i}}$ & $\mathrm{PA} / \beta$-carotene & $\mathrm{PA} / \mathrm{Mg}$ & $\mathrm{PA} / \mathrm{Fe}$ & $\mathrm{PA} / \mathrm{Mn}$ & $\mathrm{PA} / \mathrm{Zn}$ \\
\hline \multicolumn{7}{|c|}{ BSSS } \\
\hline L1 & $9.2 \pm 0.3$ & $957 \pm 16$ & $0.70 \pm 0.006$ & $77 \pm 2$ & $227 \pm 3$ & $64.8 \pm 2.0$ \\
\hline L2 & $7.0 \pm 0.5$ & $953 \pm 9$ & $0.70 \pm 0.008$ & $65 \pm 24$ & $259 \pm 3$ & $54.7 \pm 2.1$ \\
\hline L3 & $9.0 \pm 0.3$ & $950 \pm 10$ & $0.76 \pm 0.006$ & $60 \pm 3$ & $265 \pm 3$ & $45.6 \pm 1.2$ \\
\hline $\mathrm{L} 4$ & $7.5 \pm 0.5$ & $848 \pm 13$ & $0.86 \pm 0.014$ & $72 \pm 2$ & $359 \pm 2$ & $50.4 \pm 2.6$ \\
\hline L5 & $10.8 \pm 1.5$ & $1243 \pm 106$ & $0.83 \pm 0.009$ & $53 \pm 4$ & $224 \pm 2$ & $76.7 \pm 2.0$ \\
\hline L6 & $7.2 \pm 3.0$ & $1274 \pm 45$ & $0.90 \pm 0.021$ & $253 \pm 17$ & $342 \pm 3$ & $63.2 \pm 2.6$ \\
\hline L7 & $9.0 \pm 1.6$ & $808 \pm 21$ & $0.99 \pm 0.021$ & $187 \pm 9$ & $300 \pm 7$ & $81.5 \pm 5.1$ \\
\hline L8 & $8.1 \pm 1.4$ & $797 \pm 10$ & $0.76 \pm 0.046$ & $162 \pm 12$ & $176 \pm 6$ & $65.7 \pm 6.5$ \\
\hline L9 & $5.5 \pm 1.3$ & $1006 \pm 15$ & $0.69 \pm 0.020$ & $94 \pm 6$ & $152 \pm 4$ & $57.8 \pm 4.8$ \\
\hline L10 & $8.6 \pm 1.1$ & $491 \pm 6$ & $0.73 \pm 0.023$ & $88 \pm 5$ & $181 \pm 5$ & $48.4 \pm 3.9$ \\
\hline L11 & $6.3 \pm 0.4$ & $779 \pm 19$ & $0.81 \pm 0.011$ & $72 \pm 3$ & $212 \pm 4$ & $28.3 \pm 1.2$ \\
\hline L12 & $6.3 \pm 0.4$ & $622 \pm 123$ & $0.75 \pm 0.013$ & $80 \pm 3$ & $199 \pm 5$ & $36.1 \pm 2.5$ \\
\hline L13 & $8.4 \pm 1.5$ & $693 \pm 126$ & $0.70 \pm 0.011$ & $83 \pm 3$ & $287 \pm 6$ & $57.6 \pm 2.3$ \\
\hline L14 & $7.9 \pm 0.3$ & $645 \pm 4$ & $0.78 \pm 0.006$ & $81 \pm 5$ & $195 \pm 5$ & $53.9 \pm 1.3$ \\
\hline L15 & $7.1 \pm 0.2$ & $1027 \pm 5$ & $0.80 \pm 0.004$ & $78 \pm 2$ & $236 \pm 1$ & $67.1 \pm 1.2$ \\
\hline L16 & $8.9 \pm 1.8$ & $728 \pm 7$ & $0.86 \pm 0.006$ & $170 \pm 2$ & $231 \pm 2$ & $44.6 \pm 0.5$ \\
\hline L17 & $9.9 \pm 0.5$ & $1003 \pm 6$ & $0.84 \pm 0.004$ & $240 \pm 3$ & $263 \pm 1$ & $48.6 \pm 1.4$ \\
\hline L18 & $9.6 \pm 1.2$ & $723 \pm 55$ & $0.85 \pm 0.007$ & $93 \pm 1$ & $160 \pm 1$ & $53.3 \pm 1.3$ \\
\hline L19 & $9.3 \pm 0.8$ & $734 \pm 46$ & $0.94 \pm 0.023$ & $50 \pm 6$ & $333 \pm 2$ & $60.2 \pm 3.1$ \\
\hline L20 & $8.8 \pm 0.4$ & $605 \pm 8$ & $0.89 \pm 0.015$ & $59 \pm 5$ & $225 \pm 1$ & $52.1 \pm 3.7$ \\
\hline \multicolumn{7}{|c|}{ Lancaster } \\
\hline L21 & $5.9 \pm 0.4$ & $864 \pm 8$ & $0.78 \pm 0.011$ & $97 \pm 3$ & $173 \pm 2$ & $43.0 \pm 2.0$ \\
\hline L22 & $11.1 \pm 1.2$ & $969 \pm 12$ & $0.85 \pm 0.015$ & $74 \pm 2$ & $225 \pm 7$ & $91.7 \pm 3.7$ \\
\hline L23 & $8.2 \pm 4.0$ & $700 \pm 23$ & $0.85 \pm 0.022$ & $267 \pm 24$ & $274 \pm 4$ & $72.4 \pm 4.2$ \\
\hline L24 & $8.8 \pm 0.2$ & $828 \pm 6$ & $0.85 \pm 0.003$ & $134 \pm 1$ & $202 \pm 1$ & $65.2 \pm 0.9$ \\
\hline L25 & $7.1 \pm 0.2$ & $710 \pm 5$ & $0.94 \pm 0.006$ & $113 \pm 1$ & $168 \pm 1$ & $84.3 \pm 1.5$ \\
\hline L26 & $7.9 \pm 0.6$ & $586 \pm 6$ & $0.84 \pm 0.009$ & $106 \pm 2$ & $174 \pm 1$ & $69.9 \pm 2.1$ \\
\hline L27 & $8.5 \pm 0.1$ & $663 \pm 1$ & $0.83 \pm 0.004$ & $119 \pm 3$ & $146 \pm 1$ & $96.5 \pm 1.0$ \\
\hline L28 & $5.9 \pm 0.5$ & $843 \pm 15$ & $0.74 \pm 0.017$ & $103 \pm 5$ & $194 \pm 3$ & $53.3 \pm 3.4$ \\
\hline L29 & $5.9 \pm 0.7$ & $2743 \pm 255$ & $0.75 \pm 0.026$ & $82 \pm 5$ & $157 \pm 7$ & $47.4 \pm 4.2$ \\
\hline L30 & $7.1 \pm 1.2$ & $608 \pm 23$ & $0.82 \pm 0.017$ & $123 \pm 7$ & $159 \pm 2$ & $76.1 \pm 3.4$ \\
\hline L31 & $6.9 \pm 0.9$ & $2162 \pm 132$ & $0.98 \pm 0.022$ & $54 \pm 3$ & $322 \pm 2$ & $70.2 \pm 4.4$ \\
\hline L32 & $5.2 \pm 1.2$ & $618 \pm 6$ & $0.82 \pm 0.015$ & $58 \pm 5$ & $208 \pm 1$ & $48.9 \pm 3.6$ \\
\hline L33 & $6.9 \pm 1.1$ & $745 \pm 12$ & $0.90 \pm 0.015$ & $52 \pm 7$ & $217 \pm 1$ & $96.1 \pm 0.2$ \\
\hline L34 & $6.5 \pm 0.4$ & $665 \pm 8$ & $0.76 \pm 0.013$ & $77 \pm 10$ & $311 \pm 2$ & $59.2 \pm 1.9$ \\
\hline L35 & $6.3 \pm 0.6$ & $587 \pm 5$ & $0.68 \pm 0.011$ & $65 \pm 13$ & $269 \pm 1$ & $55.7 \pm 1.8$ \\
\hline L36 & $6.8 \pm 0.7$ & $768 \pm 15$ & $0.81 \pm 0.018$ & $67 \pm 3$ & $357 \pm 2$ & $40.7 \pm 1.5$ \\
\hline L37 & $8.9 \pm 1.1$ & $2697 \pm 70$ & $0.85 \pm 0.018$ & $85 \pm 10$ & $217 \pm 1$ & $45.3 \pm 2.5$ \\
\hline \multicolumn{7}{|c|}{ Independent source } \\
\hline L38 & $7.5 \pm 0.5$ & $980 \pm 8$ & $0.73 \pm 0.009$ & $91 \pm 3$ & $280 \pm 6$ & $59.1 \pm 2.0$ \\
\hline L39 & $9.6 \pm 0.3$ & $1874 \pm 24$ & $0.86 \pm 0.012$ & $91 \pm 2$ & $292 \pm 7$ & $56.7 \pm 2.3$ \\
\hline L40 & $6.1 \pm 0.3$ & $1005 \pm 30$ & $0.73 \pm 0.010$ & $117 \pm 3$ & $202 \pm 4$ & $46.9 \pm 2.1$ \\
\hline L41 & $5.1 \pm 0.2$ & $973 \pm 28$ & $0.68 \pm 0.026$ & $97 \pm 6$ & $149 \pm 2$ & $51.2 \pm 4.3$ \\
\hline L42 & $8.0 \pm 1.4$ & $697 \pm 13$ & $0.87 \pm 0.017$ & $175 \pm 8$ & $231 \pm 5$ & $52.9 \pm 4.0$ \\
\hline L43 & $7.2 \pm 0.2$ & $1990 \pm 13$ & $0.75 \pm 0.009$ & $190 \pm 6$ & $156 \pm 1$ & $78.5 \pm 2.4$ \\
\hline L44 & $6.2 \pm 0.8$ & $3778 \pm 66$ & $0.88 \pm 0.022$ & $99 \pm 5$ & $207 \pm 2$ & $52.3 \pm 3.9$ \\
\hline L45 & $8.1 \pm 1.9$ & $645 \pm 7$ & $0.77 \pm 0.013$ & $101 \pm 27$ & $159 \pm 2$ & $67.4 \pm 3.6$ \\
\hline L46 & $6.0 \pm 0.3$ & $592 \pm 7$ & $0.73 \pm 0.021$ & $45 \pm 2$ & $207 \pm 3$ & $36.4 \pm 3.9$ \\
\hline L47 & $7.9 \pm 0.5$ & $898 \pm 5$ & $0.99 \pm 0.006$ & $149 \pm 2$ & $265 \pm 10$ & $68.0 \pm 1.2$ \\
\hline L48 & $6.0 \pm 1.5$ & $959 \pm 4$ & $0.85 \pm 0.006$ & $96 \pm 1$ & $267 \pm 4$ & $64.8 \pm 1.3$ \\
\hline L49 & $10.4 \pm 3.8$ & $1063 \pm 42$ & $0.98 \pm 0.024$ & $190 \pm 9$ & $349 \pm 8$ & $50.5 \pm 3.5$ \\
\hline L50 & $6.0 \pm 0.3$ & $1215 \pm 11$ & $0.66 \pm 0.016$ & $39 \pm 9$ & $347 \pm 2$ & $37.2 \pm 0.2$ \\
\hline L51 & $6.8 \pm 2.4$ & $1222 \pm 174$ & $0.68 \pm 0.031$ & $74 \pm 3$ & $315 \pm 4$ & $59.4 \pm 17.5$ \\
\hline
\end{tabular}

The results are mean \pm standard deviation of four measurements.

source, L41 has the lowest $\mathrm{P}_{\text {phy }} / \mathrm{P}_{\mathrm{i}}$ and $\mathrm{PA} / \mathrm{Mn}$ ratios $(5.13$ and 148.8, respectively), signifying that some of the $\mathrm{P}$ in grain is not bound to PA (Lönnerdal, 2003) and that it could be absorbed in parallel with Mn. Additionally, L46 has the lowest $\mathrm{PA} / \beta$-carotene together with $\mathrm{PA} / \mathrm{Fe}$ ratio (591.5 and 45.0 , respectively) indicating improved Fe availability. This could be considered as important, since it is well known 
Figure 1. Interdependence between phytic $\mathbf{P}\left(\mathbf{P}_{\text {phy }}\right)$ and mineral elements in grain of maize lines belong to (A) BSSS heterotic group, (B) Lancaster heterotic group, and (C) Independent source.
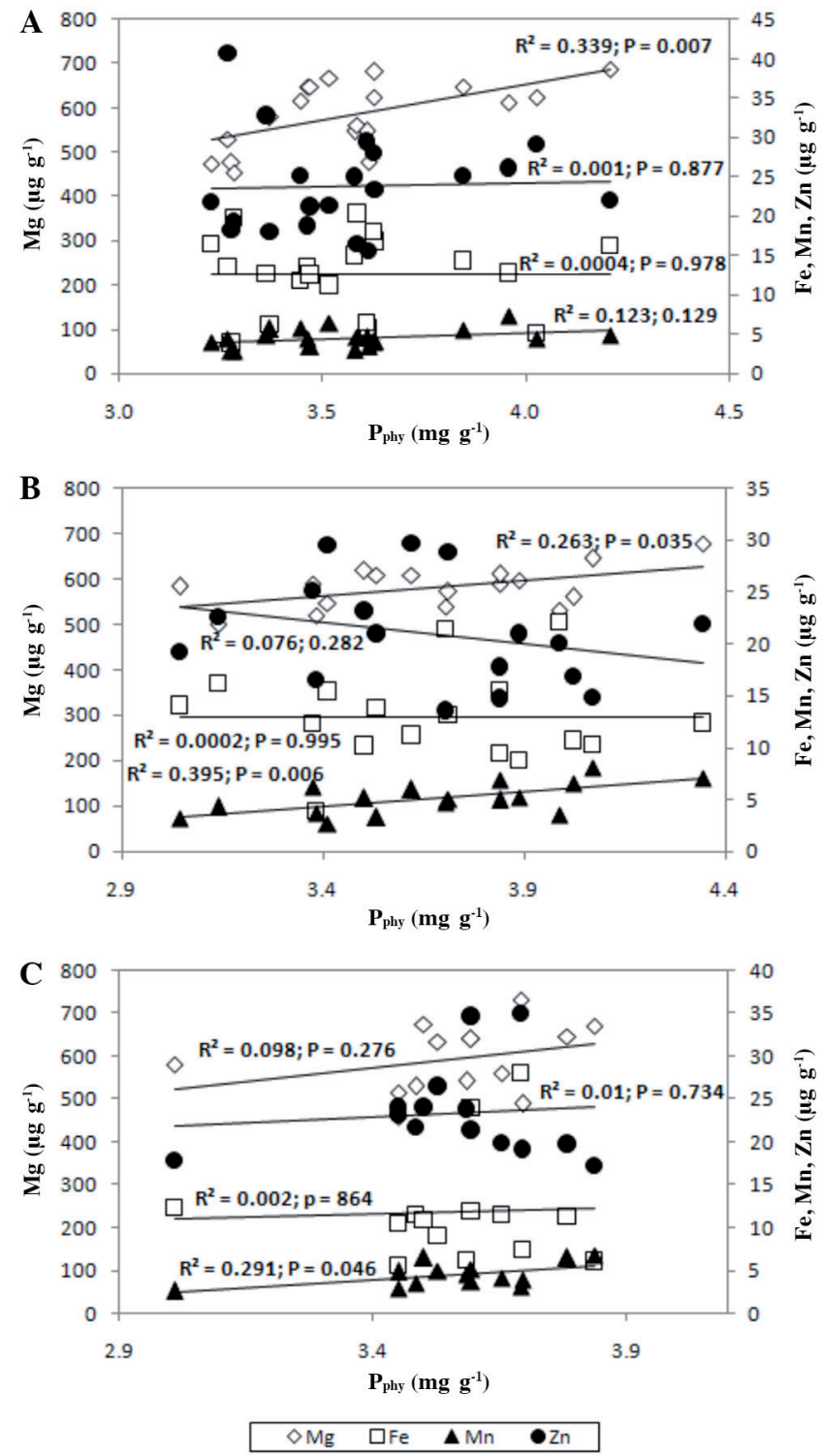

that increased $\mathrm{Fe}$ absorption by humans is associated with increased $\beta$-carotene content in foods (Lönnerdal, 2003; Calheiros et al., 2011). The lowest $\mathrm{PA} / \mathrm{Mg}$ ratio among all examined lines was found in L50 (0.66) from Independent group, the inbred with low $\mathrm{P}_{\text {phy }} / \mathrm{P}_{\mathrm{i}}$ ratio (6.0), while the lowest PA/Zn ratio was present in L11 (28.3), from BSSS group.

According to regression analysis, positive and significant interdependence between $\mathrm{P}_{\text {phy }}$ and $\mathrm{Mg}$ was observed in BSSS and Lancaster group $\left(\mathrm{R}^{2}=0.339 ; \mathrm{P} \leq 0.01\right.$ and $\mathrm{R}^{2}=0.263 ; \mathrm{P}$ $\leq 0.05$, respectively; Figure 1). In all three heterotic groups, significant and positive correlation between $\mathrm{P}_{\text {phy }}$ and $\mathrm{Mn}$ was found, with the highest regression coefficient obtained in Lancaster group $\left(\mathrm{R}^{2}=0.395 ; \mathrm{P} \leq 0.01\right)$. In addition, Ghandilyan et al. (2009) reported significant and negative correlation between PA content and Fe and $\mathrm{Zn}$ in Arabidopsis
Figure 2. Interdependence between $\beta$-carotene and mineral elements in grain of maize lines belong to (A) BSSS heterotic group, (B) Lancaster heterotic group, and (C) Independent source.
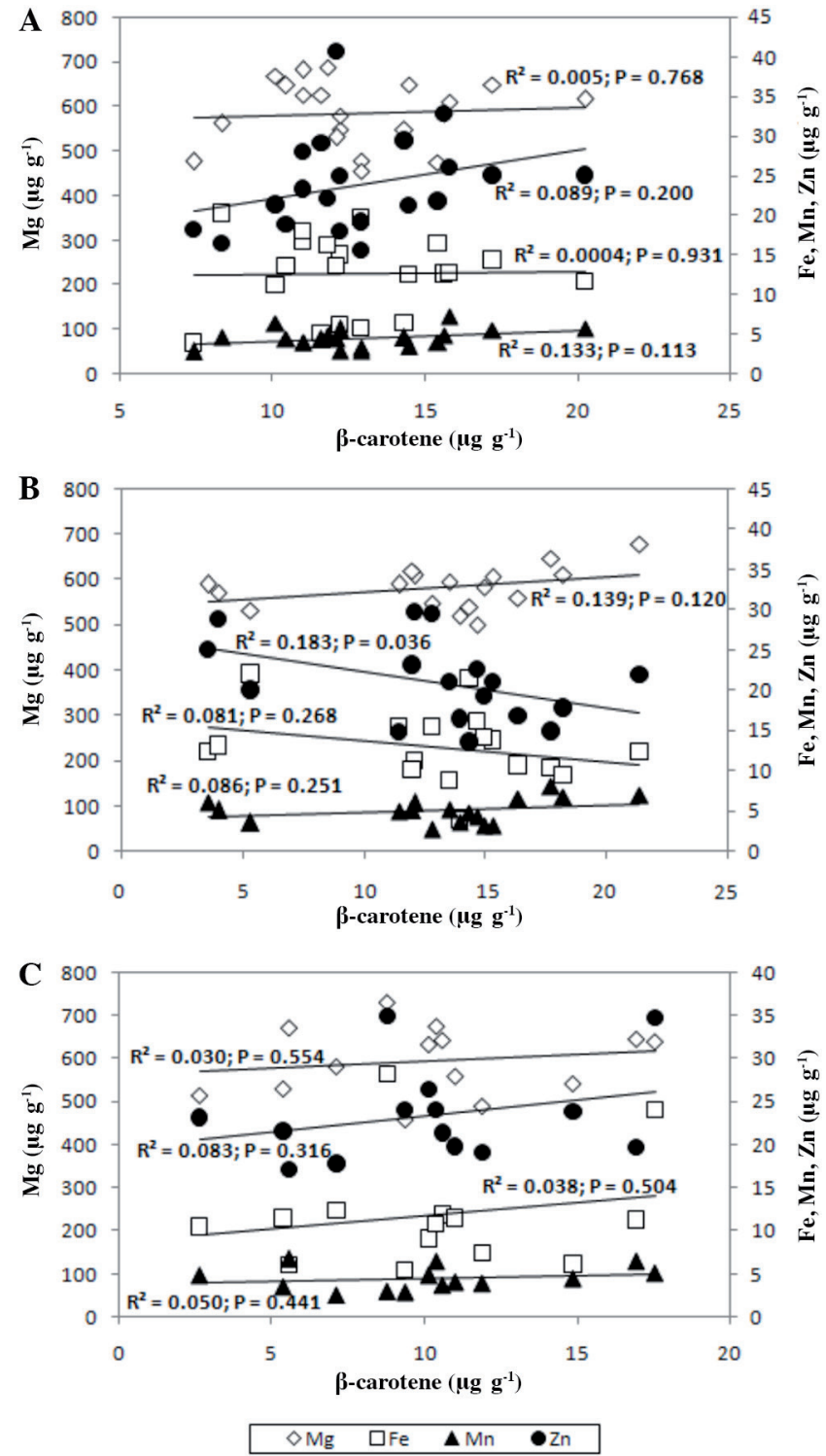

seeds, with increased impact of environment on variation of mineral elements in seeds, which is supported by the results presented in Table 1 . Interdependence between $\beta$-carotene and examined mineral elements was expressed to a lesser extent (Figure 2), with positive, but not significant correlation between $\beta$-carotene and $\mathrm{Mg}$ in Lancaster group $\left(\mathrm{R}^{2}=0.139\right)$, as well as between $\beta$-carotene and $\mathrm{Mn}$ in BSSS group $\left(\mathrm{R}^{2}\right.$ $=0.133)$. The only significant and negative correlation was observed between $\beta$-carotene and $\mathrm{Zn}$ in Lancaster group $\left(\mathrm{R}^{2}\right.$ $=0.183 ; \mathrm{P} \leq 0.05)$. This could denote that availability of $\mathrm{Mg}$ and $\mathrm{Mn}$ content, particularly from genotypes with higher content of $\mathrm{Mg}$ and $\mathrm{Mn}$ (from Lancaster group), could be restrained by increased PA content. According to the results, positive aspect of increased $\beta$-carotene content could be reflected on improved $\mathrm{Mn}$ and $\mathrm{Zn}$ availability from grain of BSSS genotypes and improved $\mathrm{Mg}$ from Lancaster inbreds. 
Figure 3. Principal Component Analysis for phytic $\mathbf{P}\left(\mathbf{P}_{\text {phy }}\right)$, inorganic $\mathbf{P}\left(\mathbf{P}_{\mathrm{i}}\right)$, $\beta$-carotene, $\mathrm{Mg}, \mathrm{Fe}$, Mn, and $\mathrm{Zn}$ content in examined maize inbred lines belong to (A) BSSS heterotic group, (B) Lancaster heterotic group, and (C) Independent source.

A

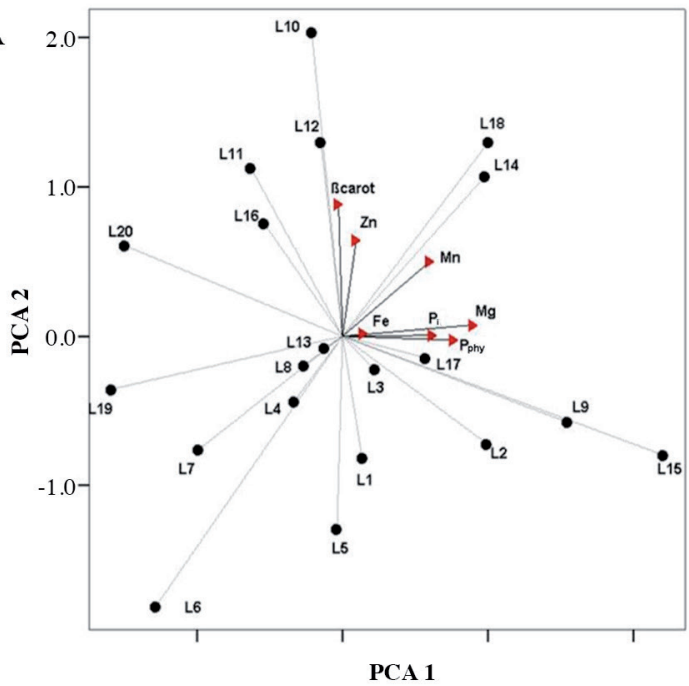

B

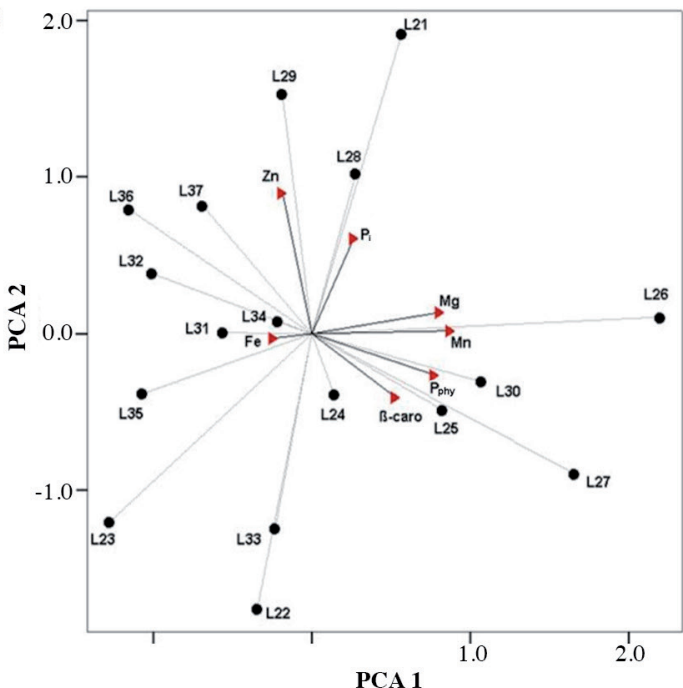

C

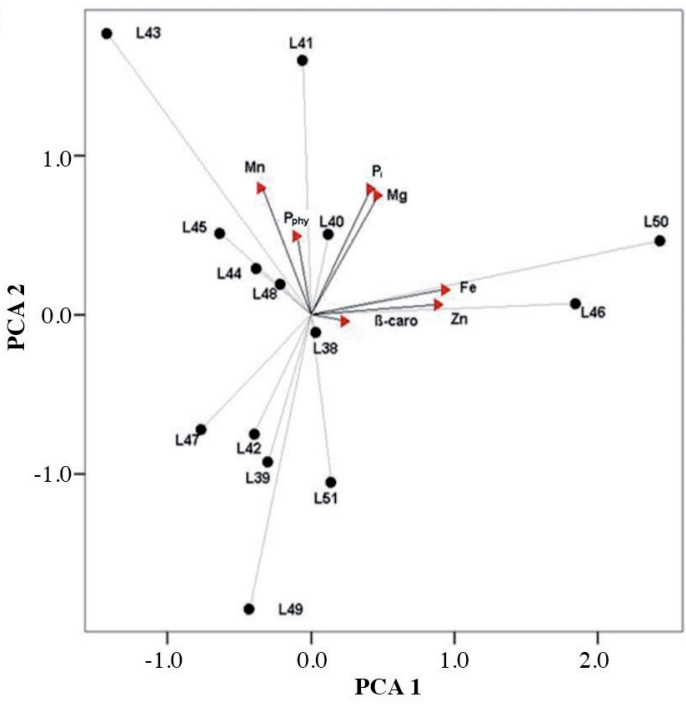

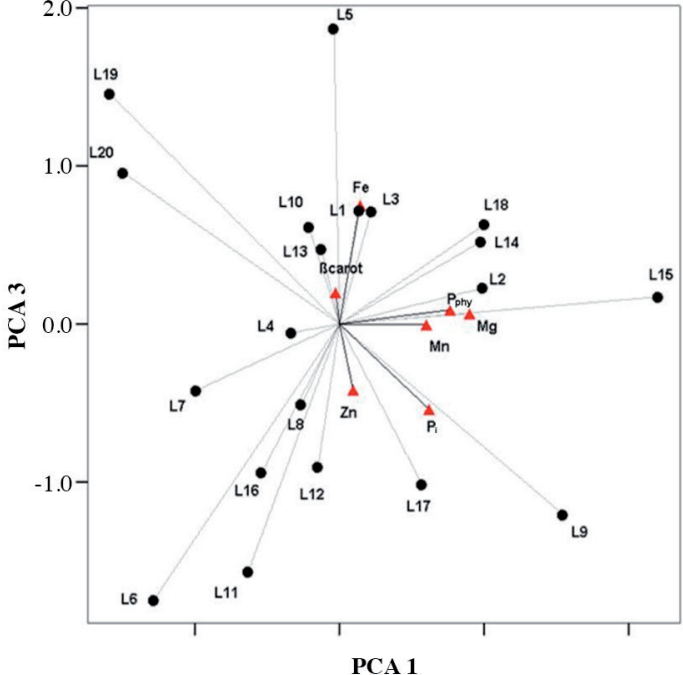

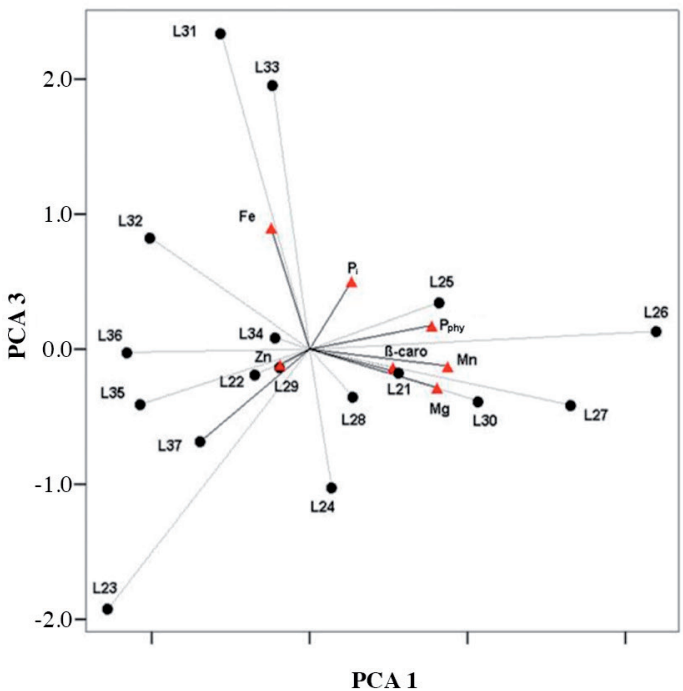

PCA 1

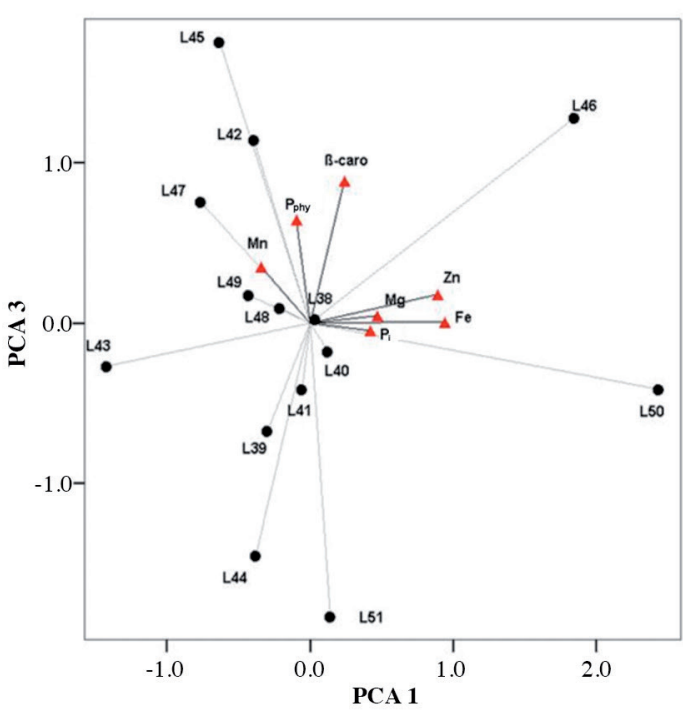


According to PCA, first three axes explained $67.309 \%$, $73.166 \%$ and $81.812 \%$ of total variability for the variables set observed (for BSSS, Lancaster, and Independent source, respectively). Projection of the variables indicated that for $B S S S$ heterotic group $\mathrm{P}_{\text {phy }}$ and $\mathrm{Mg}$ contents contributed mainly to PC1 (0.769 and 0.900, respectively; Figure 3A), $\beta$-carotene to PC2 (0.886), whereas PC3 was defined with $\mathrm{Fe}$ (0.750); for Lancaster group, $\mathrm{P}_{\text {phy }}, \mathrm{Mg}$, and $\mathrm{Mn}$ contributed mainly to PC1 $(0.771,0.806$, and 0.875 , respectively; Figure 3B), while PC2 and PC3 were determined by the contents of $\mathrm{Zn}$ and $\mathrm{Fe}$ (0.901 and 0.902, respectively). For the genotypes from Independent source, $\mathrm{Fe}$ and $\mathrm{Zn}$ contributed mainly to PC1 (0.940 and 0.893, respectively), $\mathrm{P}_{\mathrm{i}}, \mathrm{Mg}$ and $\mathrm{Mn}$ to PC2 (0.792, 0.749 and 0.799 , respectively), whereas PC3 was determined with $\beta$-carotene content $(0.887$; Figure $3 C)$. This could mean that factors which reduce $\mathrm{P}_{\text {phy }}$ content in grain induce significant decrease of $\mathrm{Mg}$ in grain of inbreds from BSSS heterotic group ( $\mathrm{r}=0.583 ; \mathrm{P} \leq 0.01)$, as well as $\mathrm{Mg}(\mathrm{r}=0.513 ; \mathrm{P} \leq 0.05)$ and $\mathrm{Mn}(\mathrm{r}=0.629 ; \mathrm{P} \leq 0.01)$ in Lancaster group. Similar trend was observed for $\mathrm{P}_{\text {phy }}$ and $\mathrm{Mn}$ contents in grain of inbreds from Independent source $(r=$ $0.540 ; \mathrm{P} \leq 0.05$ ). Only in grain of Lancaster heterotic group, $\mathrm{P}_{\text {phy }}$ reduction is followed by $\mathrm{Zn}$ content increase, while in grain of inbreds from Independent source, variations in $\mathrm{Mg}, \mathrm{Fe}$, and $\mathrm{Mn}$ contents are independent on $\mathrm{P}_{\text {phy }}$ status, indicating that the genotypes from this group (i.e. inbreds with higher $\mathrm{Mg}, \mathrm{Fe}$, and $\mathrm{Mn}$ status in grain), could serve as favorable source of improved $\mathrm{Mg}, \mathrm{Fe}$ and $\mathrm{Mn}$ absorption (Ma et al., 2007; Queiroz et al., 2011).

\section{CONCLUSIONS}

Evaluated maize inbred lines have different ability to acquire $\mathrm{Fe}, \mathrm{Mn}$, and $\mathrm{Zn}$, when grown on calcareous soil with low content of examined mineral elements. The highest $\mathrm{Fe}$ and Mn was found in inbred lines belong to Lancaster heterotic group and Zn content in lines from BSSS group. Generally, increased level of $\mathrm{Fe}$ and $\mathrm{Mn}$ in Lancaster lines could be partially affected by higher PA content in grain, while increased $\beta$-carotene content could improve $\mathrm{Mn}$ and $\mathrm{Zn}$ availability from grain of BSSS genotypes and $\mathrm{Mg}$ availability from Lancaster inbreds. It is important to underline that $\mathrm{P}_{\text {phy }}$ reduction is followed by $\mathrm{Zn}$ content increase in grain of Lancaster heterotic group, as well as that variations in $\mathrm{Mg}$, $\mathrm{Fe}$, and $\mathrm{Mn}$ contents are independent on $\mathrm{P}_{\text {phy }}$ status in inbreds from Independent source, indicating that the genotypes with higher $\mathrm{Mg}, \mathrm{Fe}$, and $\mathrm{Mn}$ status from this group could serve as favorable source of improved $\mathrm{Mg}, \mathrm{Fe}$, and $\mathrm{Mn}$ absorption. Due to the lowest PA/Mn and PA/ $\beta$-carotene ratios, inbred L10 from BSSS and L27 from Lancaster heterotic group could be considered as favorable sources for improved Mn bioavailability. Also, inbred L11, genetically related to BSSS heterotic group, could be considered as favorable source for higher $\mathrm{Zn}$ availability. Among genotypes belong to Independent source, inbred L46 could be considered as a desirable source for higher Fe availability, and maize inbred line L50 for higher Mg availability (due to lower PA content).

\section{ACKNOWLEDGEMENTS}

This study was supported by Project TR31068 from the Ministry of Education, Science and Technological Development, Republic of Serbia, and by COST Action FA 0905.

\section{REFERENCES}

AACC. 1995. Pigments. Methods 14-50. AACC Methods. $9^{\text {th }}$ ed. American Association of Cereal Chemistry (AACC), St. Paul, Minnesota, USA.

Bohn, L., A.S. Meyer, and S.K. Rasmussen. 2008. Phytate: impact on environment and human nutrition. A challenge for molecular breeding. Journal of Zhejiang University Science B 9:165-191.

Brankovic, G., V. Dragicevic, D. Dodig, M. Zoric, D. Knezevic, S. Zilic, et al. 2015. Genotype $\times$ Environment interaction for antioxidants and phytic acid contents in bread and durum wheat as influenced by climate. Chilean Journal of Agricultural Research 75:139-146.

Cakmak, I. 2008. Enrichment of cereal grains with zinc: agronomic or genetic biofortification? Plant and Soil 302:1-17.

Calheiros, K.O., and S.G. Canniatti-Brazaca. 2011. Iron availability, protein digestibility and beta-carotene amount in alternative formulated of low cost for elderly. Ciência e Tecnologia de Alimentos 31:41-55.

Dragicevic, V., S. Sredojevic, V. Peric, A. Nisavic, and M. Srebric. 2011. Validation study of a rapid colorimetric method for the determination of phytic acid and inorganic phosphorus from seeds. Acta Periodica Technologica 42:11-21.

Germano, R.M.A., and S.G. Canniatti-Brazaca. 2011. Iron availability in the presence of $\beta$-carotene in different mixtures. Ciência e Tecnologia de Alimentos 31:327-333.

Ghandilyan, A., N. Ilk, C. Hanhart, M. Mbengue, L. Barboza, H. Schat, et al. 2009. A strong effect of growth medium and organ type on the identification of QTLs for phytate and mineral concentrations in three Arabidopsis thaliana RIL populations. Journal of Experimental Botany 60:1409-1425.

Horváth, B., O. Opara-Nadi, and F. Beese. 2005. A simple method for measuring the carbonate content of soils. Soil Science Society of America Journal 69:1066-1068.

Hunt, J.R. 2003. Bioavailability of iron, zinc, and other trace minerals from vegetarian diets. American Journal of Clinical Nutrition 78 (suppl):633S-639S.

Konietzny, U., K.D. Jany, and R. Greiner. 2006. Phytate - an undesirable constituent of plant-based foods? Journal für Ernährungsmedizin 8:18-28.

Kovacevic V., I. Brkic, D. Simic, G. Bukvic, and M. Rastija. 2004. The role of genotypes on phosphorus, zinc, manganese and iron status and their relations in leaves of maize on hydromorphic soil. Plant, Soil and Environment 50:535-539.

Lönnerdal, B. 2003. Genetically modified plants for improved trace element nutrition. The Journal of Nutrition 133:1490S-1493S.

Lynch, J.P., and S.B. St.Clair. 2004. Mineral stress: the missing link in understanding how global climate change will affect plants in real world soils. Field Crops Research 90:101-115.

Ma, G., Y. Li, Y. Jin, F. Zhai, F.J. Kok, and X. Yang. 2007. Phytate intake and molar ratios of phytate to zinc, iron and calcium in the diets of people in China. European Journal of Clinical Nutrition 61:368-374.

Mehlich, A. 1984. Mehlich 3 soil test extractant: a modification of Mehlich 2 extractant. Communications in Soil Science and Plant Analysis 15:1409-1416. 
Mladenovic-Drinic, S., V. Dragicevic, M. Filipovic, M. Stojiljkovic, Z. Camdzija, D. Simic, et al. 2013. Genetic variation of macro and microelements in grain of maize inbred lines. p. 173-177. In Dušan Kovacevic (ed.) Book of Proceeding IV International Scientific Symposium “Agrosym 2013” Jahorina. 3-6 October. Faculty of Agriculture, University of East Sarajevo, Bosnia and Herzegovina.

Nielsen, F.H. 2010. Magnesium, inflammation, and obesity in chronic disease. Nutrition Reviews 68:333-340.

Ortiz-Monasterio, J.I., N. Palacios-Rojas, E. Meng, K. Pixley, R. Trethowan, and R.J. Peña. 2007. Enhancing the mineral and vitamin content of wheat and maize through plant breeding. Journal of Cereal Science 46:293-307.

Queiroz, V.A.V., P.E.O. Guimarães, L.R. Queiroz, E.O. Guedes, V.D.B. Vasconcelos, L.J. Guimarães, et al. 2011. Iron and zinc availability in maize lines. Ciência e Tecnologia de Alimentos 31:577-583.

Ramirez-Cardenasi, L., A.J. Leonel, and N.M.B. Costa. 2008. Effect of domestic processing on nutrient and antinutritional factor content in different cultivars of common beans. Ciência e Tecnologia de Alimentos 28:200-213.

Scharpf, H.C., und J. Wehrmann. 1975. Die Bedeutung des Mineralstickstoffvorrates des Bodens zu Vegetationsbeginn für die Bemessung der N-Düngung zu Winterweizen. Landwirtschaftlicher Forschung 32:100-114.
Watanabe,F.S., and S.R. Olsen. 1965. Test of an ascorbic acid method for determining phosphorus in water and $\mathrm{NaHCO}_{3}$ extracts from the soil. Soil Science Society of America 29:677-678.

Welch, R.M. 2003. Farming for nutritious foods: Agricultural technologies for improved human health. p. 1-24. Agriculture Conference Global Food Security and the Role of Sustainable Fertilization, Rome. 26-28 March. International Fertilizer Industry Association (IFA)-FAO, Rome, Italy.

Welch, R.M., and R.D. Graham. 2004. Breeding for micronutrients in staple food crops from a human nutrition perspective. Journal of Experimental Botany 55:353-364.

White, P.J., and M.R. Broadley. 2005. Biofortifying crops with essential mineral elements. Trends in Plant Science 10:586-593.

White, P.J., and M.R. Broadley. 2009. Biofortification of crops with seven mineral elements often lacking in human diets - iron, zinc, copper, calcium, magnesium, selenium and iodine. New Phytologist 182:49-84.

Zivkovic, B., V. Nejgebauer, Dj. Tanasijevic, N. Miljkovic, L. Stojkovic, and P. Drezgic. 1972. Soils of Vojvodina (In Serbian), Institute for Agricultural Research, Novi Sad, Serbia. 